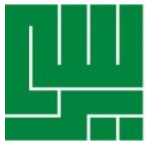

\title{
Perilaku Online Beresiko Remaja: Hubungannya dengan Kualitas Hidup dan Mediasi Orang Tua
}

\author{
Adolescents' Risky Online Behavior: Its Relationship with \\ Quality of Life and Parental Mediation
}

\author{
Zulfa Febriani, Octaviani I. Ranakusuma \\ Fakultas Psikologi Universitas YARSI \\ Email: zulfa.febriani@yarsi.ac.id
}

\section{KATA KUNCI Kualitas Hidup, Mediasi Orang Tua, Perilaku Online Beresiko, Remaja. \\ KEYWORDS Quality of Life, Parental Mediation, Risky Online Behavior, Adolescents.}

ABSTRAK Remaja di kota besar di Indonesia termasuk kelompok dengan penetrasi pengguna internet tertinggi. Kebanyakan mereka menggunakan aplikasi media sosial. Hal ini membuat mereka rentan terlibat perilaku online beresiko yang antara lain adalah memberikan informasi personal dan mengakses atau terpapar konten seksual. Resiko ini dapat berdampak pada sikap permisif remaja terhadap seksualitas dan mengganggu aspek perkembangan hidupnya. Faktor yang melatarbelakangi keterlibatan remaja pada aktivitas beresiko antara lain pengawasan keluarga dan keadaan psikososial remaja. Penelitian di Indonesia belum banyak yang meneliti secara langsung peran faktor-faktor tersebut terhadap perilaku online beresiko remaja. Oleh karena itu penelitian ini bertujuan untuk mengetahui peran kualitas hidup remaja dan pengawasan orang tua (parental mediation) terhadap perilaku online beresiko seksual remaja. Partisipan adalah 148 orang remaja Jakarta dengan teknik sampel insidental. Alat ukur yang digunakan adalah EU KIDS ONLINE sub parental mediation, online risky activity, dan risky sexual activity serta KIDSCREEN-27. Penelitian ini merupakan penelitian asosiatif dengan teknik analisis korelasi Spearman dan One-way Anova. Hasil penelitian menunjukkan bahwa parental technical mediation berkaitan dengan perilaku online beresiko penyebar konten seksual dan kualitas hidup domain kesehatan dan aktivitas fisik berhubungan secara positif dan signifikan namun hubungannya lemah. Penelitian selanjutnya perlu memerhatikan aspek representasi sampel dan juga social desirability dari aitem-aitem perilaku online beresiko. Adapun literasi penggunaan internet secara teknis dan interaksi perlu semakin ditingkatkan.

ABSTRACT Adolescents in urban area of Indonesia have become the highest internet users. Most of them were social media consumers. They are exposed in risky online behavior, which included giving personal information and accessing sexual content. The activities could affect to adolescents' permissiveness about sexuality and interfere with their psychological 
development. Among the factors associated to risky behavior were parental monitoring and adolescent psychososial condition, but there was not many study in Indonesia that directly see the relationship of the factors in adolescents' risky sexual online behavior. Therefore, the study aimed to know wheater adolescents' quality of life and parental mediation associated to their risky sexual online behavior. Participants were 148 adolescents in Jakarta by accidental sampling technique. We used EU KIDS ONLINE sub parental mediation, online risky activity, risky sexual activity and KIDSCREEN-27 as instrument. The data was analyzed by Spearman correlation and One-way Anova. Results indicated that parental technical mediation and physical activity and health associated to risky sexual activity as the perpetator. Any research of the same topic should consider the sample representativeness and social desirability of the risky sexual online behavior scale. Literacy about the safety of technical internet use and interaction needs to be increased.

\section{PENDAHULUAN}

Penggunaan internet saat ini semakin pesat bahkan di kalangan remaja. Terutama di Indonesia yang merupakan salah satu negara dengan pengguna internet tertinggi. Berdasarkan survey APJII tahun 2017, penetrasi pengguna internet pada remaja golongan usia 13-18 tahun mencapai 75,5\%. Lalu survey APJII tahun 2018 menunjukkan bahwa penetrasi golongan usia tersebut bertambah hingga mencapai $90 \%$. Internet tersebut digunakan terutama untuk media sosial. Dengan demikian dapat dikatakan bahwa di antara populasi remaja, hampir seluruhnya menggunakan internet. Internet dapat membuat remaja terlibat pada aktivitas online yang beresiko. Aktivitas online beresiko yang paling sering dilakukan adalah memberikan informasi personal. Selanjutnya, aktivitas yang paling banyak adalah mengakses konten seksual (Livingstone \& Haddon, 2009). Hal ini sejalan dengan penelitian pada mahasiswa di Turki bahwa 51\% dari 1330 orang mengaskses internet untuk memperoleh informasi mengenai seksualitas (Ucar, Golbasi, \& Erenel, 2016). Di Indonesia, penelitian pada 60 remaja usia 15-24 tahun di Yogyakarta menunjukkan bahwa 63\% mengakses pornografi melalui internet meskipun dengan intensitas yang jarang (kurang dari 2,5 jam per minggu) (Lestari, Suherni, \& Kusmiyati, 2015). Penelitian lain di Madura pada 80 orang siswa SMPSMA/SMK menunjukkan bahwa $91 \%$ partisipan tanpa sengaja terpapar pornografi saat mengakses internet dan 35\% mengaku mengakses secara sengaja dan kebanyakan dilakukan oleh remaja laki-laki (Ramadani \& Hanna, 2019). Hal ini menunjukkan bahwa remaja saat ini telah terlibat dengan aktivitas online yang beresiko.

Internet dapat memiliki efek negatif untuk remaja. Aplikasi media sosial, misalnya, dapat berdampak pada harga diri dan kesejahteraan remaja terkait dengan konten dan feedback yang didapat remaja ketika mengaksesnya (Volkenburg, Peter, $\&$ Scouten, 2006). Selain itu, banyak penelitian yang menunjukkan bahwa aktivitas di internet secara umum dapat mengganggu aktivitas rutin dan istirahat remaja, mengganggu kemampuan konsentrasi (Barlett, Gentile, Barlett, Eisenmann, \& Walsh, 2011) dan secara umum menurunkan kesehatan mental remaja (Iannotti, Kogan, Janssen, \& Boyce, 2009; Finne, Bucksch, Lampert, \& Kolip, 2014). Sedangkan terkait paparan terhadap konten seksual, penelitian Zilmann (dalam Braun-Courville \& Rojas, 2009) menunjukkan dampaknya secara 
berkelanjutan adalah menguatkan belief mengenai aktivitas seksual di antara peer dan sikap permisif secara seksual. Hal ini sejalan dengan hasil penelitian Lestari, Suherni, dan Kusmiyati (2015) yang menemukan hubungan yang positif dan kuat antara intensitas mengakses situs porno dengan perilaku seksual pranikah remaja dan penelitian Naja, Agushybana, dan Mawarni (2017) yang menunjukkan bahwa $93,7 \%$ remaja yang melakukan perilaku seskual pranikah adalah mereka yang terpapar pada media sosial berkonten seksual. Oleh karena itu, peneliti akan memfokuskan perilaku online beresiko yang berkaitan dengan konten seksual.

Perilaku online beresiko seksual adalah mendapatkan gambar atau tayangan dengan konten seksual, sexting (memposting atau bertukar gambar atau pesan yang memuat konteks seksual), atau dikontak oleh orang yang tidak dikenal dan diajak berbicara atau melakukan sesuatu yang berkaitan dengan seks (Noll, Shenk, Barnes, \& Haralson, 2013; Baumgartner, Valkenburg, \& Peter, 2010; Houck dkk, 2014). Menurut Livingstone, Haddon, Görzig, dan Olafsson (2011), aktivitas online beresiko seperti memberikan informasi personal dan berkenalan online dengan orang yang tidak dikenal sama sekali di lingkungan sehari-hari merupakan peluang besar untuk masuk ke perilaku online beresiko seksual. Dengan demikian, perilaku online beresiko seksual dalam penelitian yang dimaksud merupakan aktivitas online beresiko, menerima maupun menyebar pesan konten seksual baik berupa pembicaraam, teks, gambar, ataupun video.

Hasil penelitian menunjukkan bahwa perilaku beresiko seperti perilaku seksual tidak aman, penggunaan dan pengedaran napza berkorelasi negatif dengan persepsi terhadap parental monitoring khususnya pada anak-anak dan remaja dari keluarga Afrika-Amerika perkotaan yang berpendapatan rendah $(\mathrm{Li}$, Stanton, \& Feigelman, 2000). Artinya, semakin remaja mempersepsi adanya parental monitoring dari orang tua, maka keterlibatan mereka terhadap perilaku beresiko semakin rendah. Suwarni (2009) juga telah menemukan bahwa parental monitoring memiliki peran langsung terkait perilaku seksual pranikah remaja meskipun perannya kecil. Ketika dikaitkan dengan perilaku beresiko dalam penggunaan media dan internet, maka parental monitoring diistilahkan dengan parental mediation. Parental mediation merupakan aktivitas orang tua yang bertujuan untuk melindungi anak-anaknya dari paparan aktivitas online yang berbahaya dan beresiko (Livingstone, dalam Sasson \& Mesch, 2014; dalam Mesch, 2009).

Parental mediation secara lebih rinci lagi terbagi menjadi beberapa pendekatan khususnya terkait dalam penggunaan internet oleh remaja. Pendekatan tersebut ada lima dimensi yaitu: active mediation of internet use yang mana orang tua hadir atau berada di dekat anak serta mendorong anak untuk berbagi atau mendiskusikan aktivitas internet; active mediation of internet safety yang mana orang tua membimbing anak menggunakan internet secara aman, membantu atau mendiskusikan cara menghadapi kesulitan dalam berinternet; restrictive mediaton yang mana orang tua menentukan aturan dan batasan bagi anak dalam penggunaan internet; monitoring yang mana orang tua mengawasi jejak penggunaan internet anak; dan technical mediation yang mana orang tua menggunakan program atau pengaturan orang tua dalam menyaring, membatasi atau memantau anak dalam penggunaan internet (Livingstone dkk, 2011).

Sejalan dengan penelitian $\mathrm{Li} \mathrm{dkk}$ (2000) yang menyebutkan bahwa pengawasan orang tua yang rendah berkaitan dengan peningkatan perilaku beresiko pada remaja, maka parental mediation yang buruk juga berkaitan erat dengan keterlibatan remaja pada perilaku online berbahaya dan bersifat agresif (Sasson \& Mesch, 2014). Dengan demikian, parental mediation merupakan salah satu faktor pelindung yang diperlukan untuk 
meminimalisasi keterlibatan remaja pada perilaku online beresiko seksual.

Selain faktor pengawasan orang tua, perilaku online beresiko juga berkaitan dengan faktor psikososial yang dimiliki remaja seperti masalah emosional, masalah dengan pertemanan, hiperaktivitas (Goodman, Ford, Simmon,s, Gatward, \& Meltzer, dalam Livingstone \& Görzig, 2014). Mereka yang memiliki hambatan psikologis ini lebih mudah terpapar atau mencari aktivitas online yang beresiko (Wells \& Mitchell, dalam Livingstone \& Görzig, 2014). Mereka yang kurang merasa puas dengan kehidupannya juga cenderung meningkatkan perilaku online beresiko. Usia yang lebih tua dan intensitas penggunaan internet yang lebih tinggi serta kondisi sosial remaja yang lebih buruk juga berkaitan dengan perilaku online beresiko yang lebih besar (Livingstone \& Helsper, 2007; Livingstone \& Haddon, 2009; Paluckaitė \& -Matulaitienè, 2016). Masalah emosional, pertemanan, hambatan psikologis, perasaan kurang puas terhadap kehidupan dan hal-hal yang terkait dengan perilaku online beresiko yang disebutkan pada penelitian tersebut merupakan bagian dari kualitas hidup.

Konsep kualitas hidup mencakup aspek yang luas dan umumnya berkaitan dengan kualitas hidup yang berkaitan dengan kesehatan dan berbagai dimensi kesejahteraan hidup manusia. Pada anakanak dan remaja, pengukuran kualitas hidup mencakup informasi mengenai keberfungsian anak dan remaja sehari-hari dalam konteks keluarga dan sekolah. Mengukur kualitas hidup pada anak-anak dan remaja dapat menjadi salah satu strategi dalam mengevaluasi pengaruh beban konteks sosial tertentu seperti indikator faktor sosiodemografis yang buruk, misalnya kemiskinan, lingkungan sekolah yang buruk, kondisi keluarga, dan kondisi yang terkait kesehatan anak dan remaja itu sendiri (Berman, Liu, Ullman, Jadbäck, \& Engström, 2016).

Penelitian di Indonesia mengenai faktor-faktor yang terkait perilaku online beresiko seksual pada remaja belum banyak dilakukan, meskipun penelitian tentang kaitan maupun peran paparan pornografi terhadap perilaku seksual remaja telah ada. Oleh karena itu, peneliti ingin mengetahui kaitan mediasi orang tua dan kualitas hidup remaja dengan perilaku online beresiko seksual remaja.

\section{METODE PENELITIAN Desain}

Penelitian ini merupakan penelitian asosiatif yang bertujuan untuk mengetahui kaitan antara kualitas hidup remaja dan parental mediation dengan perilaku online beresiko remaja.

\section{Partisipan}

Partisipan berjumlah 148 remaja yang menggunakan internet dan tinggal di Jakarta. Partisipan dipilih dengan teknik nonprobability sampling secara insidental.

\section{Instrumen}

Data dalam penelitian ini akan dikumpulkan melalui kuesioner. Kuesioner terdiri dari skala perilaku online beresiko, skala kualitas hidup, skala parental mediation, data demografi partisipan berupa usia, jenis kelamin, pendidikan, tempat tinggal, dan status sosial ekonomi. Untuk mendapatkan gambaran yang lengkap mengenai kebiasaan online remaja, peneliti juga menanyakan jenis aktivitas apa saja yang biasa remaja lakukan ketika menggunakan internet, seberapa besar frekuensi dan intensitasnya dalam satu pekan.

Skala perilaku online beresiko yang digunakan adalah EUKIDS Online II (Livingstone dkk, 2011). Peneliti mengadaptasi dan memodifikasi kuesioner dengan mengambil aitem-aitem yang terkait dengan aktivitas online beresiko secara umum dan resiko konten seksual. Aitemaitem berjumlah 15 butir dengan pembagian dimensi berupa aktivitas internet yang beresiko sebanyak 5 aitem, resiko terpapar (menerima) konten seksual sebanyak 5 aitem, dan ikut terlibat dalam penyebaran 
konten seksual sebanyak 5 aitem. Peneliti juga memodifikasi rentang pilihan jawaban yang tadinya berkisar antara 4 (setiap hari/hampir setiap hari), 3 (sekali-dua kali seminggu), 2 (sekali-dua kali sebulan), 1 (lebih jarang lagi), 0 (tidak tahu), menjadi 6 (setiap hari), 5 (hampir setiap hari), 4 (sekali-dua kali seminggu), 3 (sekali-dua kali sebulan), 2 (lebih jarang lagi), dan 1 (tidak pernah). Hal ini peneliti lakukan agar kriteria pilihan jawaban menjadi lebih jelas perbedaannya antara rentang yang selalu/sering dilakukan hingga yang tidak pernah.

Parental mediation diukur dengan menggunakan kuesioner EUKIDS Online II sub mediation (Livingstone dkk, 2011). Sub skala ini terdiri atas 5 dimensi mediasi orang tua yaitu; active mediation of internet use sebanyak 5 aitem, active mediation of internet safety sebanyak 6 aitem, restrictive mediation sebanyak 6 aitem, parental monitoring sebanyak 4 aitem, dan technical mediation sebanyak 4 aitem. Pilihan jawaban terdiri atas tidak sesuai, agak sesuai, dan sesuai. Skor 0 diberikan apabila remaja menjawab tidak sesuai, sementara skor 1 diberikan untuk jawaban agak sesuai maupun sesuai sehingga dikategorikan telah melakukan parental mediation.

Kualitas hidup diukur dengan KIDSCREEN-27. Kuesioner ini mengukur persepsi remaja terhadap kualitas hidupnya pada lima dimensi yaitu kesehatan dan aktivitas fisik secara umum, perasaan dan mood remaja secara umum, suasana keluarga dan waktu luang, pertemanan, dan penyesuaian dalam lingkungan sekolah. Pilihan jawaban berkisar dari 1 (tidak pernah) sampai 5 (selalu/sangat sering) (Berman dkk, 2016).

Peneliti melakukan translasi dan expert judgement dengan meminta pendapat dari dosen psikologi yang melakukan penelitian di bidang internet yang bergelar S3 dan S2. Setelah menyesuaikan aitemaitem terjemahan dengan pendapat expert, peneliti melakukan back translation kepada pekerja yang telah lebih dari 10 tahun bekerja di salah satu NGO internasional.
Peneliti kemudian melakukan uji keterbacaan dan melakukan uji coba kuesioner pada 27 anak usia 13-18 tahun.

Alat ukur EUKIDS Online II sub parental mediation memiliki indeks reliabilitas Cronbach alpha yang baik (restrictive mediation memiliki nilai $\alpha=$ .794 , parental monitoring memiliki nilai $\alpha$ $=.759$, active mediation of internet safety memiliki nilai $\alpha=.724$ ). Sementara active mediation of internet use memiliki nilai $\alpha=$ .554 dan technical mediation memiliki nilai $\alpha=.361$. Nilai reliabilitas yang kurang memuaskan pada mediation of internet use dan technical mediation dapat disebabkan oleh sedikitnya partisipan yang digunakan untuk ujicoba. Selain itu, pada mediation of technical use, aitem terakhir berkaitan dengan program antivirus dan junk menurut Dürager dan Sonck (2014) dianggap mengukur aspek yang lain dan dapat dikeluarkan dari skala, nilai korelasi dengan aitem total pun -.097. Apabila aitem ini dihapus, dapat meningkatkan nilai $\alpha$ menjadi .650 .

Alat ukur KIDSCREEN-27 memiliki indeks reliabilitas Cronbach alpha yang cukup. Dimensi kesehatan dan aktivitas fisik secara umum memiliki nilai $\alpha$ $=.554$, perasaan dan mood remaja secara umum memiliki nilai $\alpha=.618$, suasana keluarga dan waktu luang memiliki nilai $\alpha$ $=.848$, pertemanan memiliki nilai $\alpha=.593$, dan penyesuaian dalam lingkungan sekolah memiliki nilai $\alpha=.617$. Ada beberapa aitem yang indeks korelasinya dengan skor total adalah < .20. Hal ini perlu ditinjau pada saat pengambilan data dengan sampel yang lebih banyak meskipun saat ini indeks reliabilitasnya cukup.

Alat ukur EUKIDS Online II berkaitan dengan perilaku online beresiko memiliki indeks reliabilitas yang cukup. Divisi aktivitas beresiko memiliki nilai $\alpha=$ .643, divisi resiko penerima konten seksual memiliki nilai $\alpha=.651$, dan divisi resiko penyebar konten seksual memiliki nilai $\alpha=$ .680. Pada tiap dimensi terdapat aitem yang nilai korelasi dengan skor totalnya $<.20$. Pada dasarnya aitem ini perlu ditinjau 
ulang. Namun apabila aitem ini dihapus ternyata juga tidak cukup besar dalam menaikkan indeks reliabilitas skala. Hal ini dapat saja disebabkan oleh jumah partisipan uji penelitian yang < 30 .

Tabel 1

Pilot Study Uji Reliabilitas dan Korelasi Antar Aitem pada Tiap Skala Pengukuran

\begin{tabular}{lcccc}
\hline \multicolumn{1}{c}{ Dimensi } & $\begin{array}{c}\text { N } \\
\text { aitem }\end{array}$ & N & $\begin{array}{c}\text { Korelasi aitem } \\
\text { dengan skor dimensi }\end{array}$ & $\alpha$ \\
\hline Perilaku online beresiko & & & & \\
Aktivitas online beresiko & 5 & 27 & $.090-.651$ & .643 \\
Resiko penerima konten seksual & 5 & 27 & $.000-.768$ & .651 \\
Resiko penyebar konten seksual & 5 & 27 & $.000-.943$ & .680 \\
& & & & \\
Parental mediation & & & & .554 \\
Active mediation of internet use & 5 & 27 & $.034-.605$ & .724 \\
Active mediation of internet safety & 6 & 27 & $.309-.715$ & .794 \\
Restrictive mediation & 6 & 27 & $.329-.725$ & .759 \\
Parental monitoring & 4 & 27 & $.377-.755$ & .361 \\
Tachnical mediation & 4 & 27 & $-.097-.557$ & \\
& & & & .510 \\
KIDSCREEN-27 & & & & .618 \\
Kesehatan dan aktivitas fisik & 5 & 27 & $-.047-.575$ & .548 \\
Mood dan emosi umum & 7 & 27 & $.192-.580$ & .617 \\
Keluarga dan waktu luang & 7 & 27 & $.474-.782$ & $.287-.464$ \\
Hubungan pertemanan & 4 & 27 & $.177-.565$ & \\
Lingkungan sekolah dan belajar & 4 & 27 & & \\
\hline
\end{tabular}

\section{Teknik Analisis Data}

Data dalam penelitian ini dianalisis dengan menggunakan one way anova dan analisis korelasi Spearman.

\section{ANALISIS DAN HASIL}

Penelitian ini dilakukan pada 148 remaja Jakarta dengan rata-rata usia 15,27 tahun. Partisipan laki-laki berjumlah 71 dan perempuan berjumlah 74 orang. Partisipan sebagian besar bertempat tinggal di Jakarta Utara (47,3\%), selanjutnya adalah Jakarta Pusat (20,9\%), Jakarta Timur (20,9\%), selebihnya Jakarta Barat dan Selatan $(10,1 \%)$. Kebanyakan partisipan berasal dari sekolah menengah atas $(60,8 \%)$ sementara selebihnya berada pada sekolah tingkat menengah pertama. Sebanyak $64,1 \%$ partisipan berasal dari kelas sosial ekonomi rendah, lalu masing-masing 15,5\% berasal dari kelas sosial ekonomi menengah dan atas.
Sebanyak 123 partisipan $(85,8 \%)$ menggunakan HP untuk berinternet. Sebanyak 63,3\% menggunakan internet untuk media sosial, 18,2\% untuk hiburan, sisanya untuk informasi. Kebanyakan menggunakan internet setiap hari $(60,1 \%)$ dan hampir setiap hari $(29,1 \%)$. Sebagian $(53,4 \%)$ menggunakan internet dengan durasi yang tinggi ( $\geq 5-6$ jam sehari), disusul dengan durasi yang sedang (3-4 jam sehari) sebanyak $23 \%$, dan sisanya menggunakan internet dengan durasi ringan (1-2 jam sehari).

Secara deskriptif, partisipan pada penelitian ini mempersepsi adanya active mediation of internet use and safety sebanyak $75 \%$, sebanyak $85 \%$ juga menganggap orang tuanya melakukan restrictive mediation, $50,7 \%$ menganggap orang tuanya melakukan parental monitoring, dan 73,6\% menganggap orang tuanya tidak ada yang melakukan technical mediation. Secara kesehatan dan aktivitas 
fisik, sebagian besar (62,5\%) partisipan berada pada taraf yang cukup baik, sebagain besar $(59,9 \%)$ partisipan juga berada pada status perasaan dan mood yang cukup baik, sebanyak $52 \%$ juga merasa cukup nyaman dengan suasana keluarga dan waktu luang yang dimiliki, 50\% merasa memiliki pertemanan yang cukup mendukung, dan 43,9\% merasa cukup dapat menyesuaikan diri dengan lingkungan sekolah. Berkaitan dengan perilaku online beresiko, sebanyak $63,5 \%$ mengaku setidaknya sekali-dua kali dalam sebulan terlibat dengan aktivitas internet yang beresiko, 25,3\% mengatakan setidaknya sekali-dua kali dalam seminggu terlibat dengan aktivitas internet beresiko, $10,1 \%$ mengatakan tidak pernah dan sisanya sering terlibat dengan aktivitas internet beresiko. Berkaitan dengan menerima atau diajak terlibat konten seksual, sebanyak 48,6\% mengaku tidak pernah menerima konten seksual, 41,9\% mengatakan setidaknya sekali-dua kali dalam sebulan menerima atau diajak terlibat konten seksual, dan sisanya sering menerima atau diajak terlibat konten sesksual. Sedangkan berkaitan dengan pihak yang secara sengaja melibatkan diri dengan penyebaran konten seksual, 77\% mengaku tidak pernah menjadi penyebar konten seksual dan 21,6\% mengaku setidaknya sekali-dua kali dalam sebulan terlibat dalam penyebaran konten seksual.

Peneliti melakukan uji one way anova untuk melihat kaitan parental mediation yang merupakan variabel dikotomi dengan perilaku online behavior yang merupakan variabel rasio. Hasil uji one way anova pada parental mediation terhadap perilaku online beresiko menunjukkan tidak ada peran dari masing-masing jenis parental mediation terhadap perilaku online beresiko remaja kecuali pada parental technical mediation dan penyebar konten seksual. Remaja yang tidak mendapatkan parental technical mediation lebih cenderung terlibat dalam perilaku online beresiko sebagai penyebar konten seksual $(\mathrm{F}=4.33, \mathrm{p}<.05)$.

Tabel 2

Analisis One-way Anova antara Perilaku Online Beresiko dan Parental Mediation

\begin{tabular}{ccccccccccc}
\hline Variabel & $\begin{array}{c}\text { Active } \\
\text { Mediation } \\
\text { Safety }\end{array}$ & $\begin{array}{c}\text { Active } \\
\text { Mediation } \\
\text { Use }\end{array}$ & Restrictive & \multicolumn{2}{c}{$\begin{array}{c}\text { Parental } \\
\text { Mediation }\end{array}$} & & \multicolumn{2}{c}{$\begin{array}{c}\text { Parental } \\
\text { Mechnical } \\
\text { Mediation }\end{array}$} \\
\cline { 2 - 11 } & $\mathrm{F}$ & $\mathrm{p}$ & $\mathrm{F}$ & $\mathrm{p}$ & $\mathrm{F}$ & $\mathrm{p}$ & $\mathrm{F}$ & $\mathrm{p}$ & $\mathrm{F}$ & $\mathrm{p}$ \\
\hline ORA $^{*}$ & .014 & .906 & .381 & .538 & .229 & .633 & 3.47 & .064 & .087 & .769 \\
REC $^{*}$ & .012 & .911 & .110 & .741 & .049 & .825 & 2.78 & .097 & .010 & .919 \\
PER $^{*}$ & .661 & .417 & 2.31 & .131 & .744 & .390 & 3.55 & .061 & $\mathbf{4 . 3 3}$ & $\mathbf{. 0 3 9 * *}$ \\
\hline
\end{tabular}

*ORA : Online risky activity, REC: menerima konten seksual, PER: menyebar konten seksual $* * p<.05$.

Peneliti melakukan uji korelasi Spearman untuk mengetahui hubungan kualitas hidup dengan perilaku online beresiko. Peneliti tidak menemukan hubungan yang signifikan antara tiap domain kualitas hidup dengan perilaku online beresiko, kecuali pada domain kesehatan dan aktivitas fisik $(r=.187$, $\mathrm{p}<0,05)$. Hubungan domain kesehatan dan aktivitas fisik ini dengan tipe perilaku online beresiko penyebar konten seksual bersifat positif namun lemah. 
Tabel 3

Korelasi Spearman antara Kualitas Hidup Remaja dengan Perilaku Online Beresiko

\begin{tabular}{|c|c|c|c|c|c|c|c|c|c|c|}
\hline \multirow[t]{2}{*}{ Variabel } & \multicolumn{2}{|c|}{$\begin{array}{l}\text { Kesehatan \& } \\
\text { aktivitas fisik }\end{array}$} & \multicolumn{2}{|c|}{$\begin{array}{c}\text { Mood dan } \\
\text { emosi }\end{array}$} & \multicolumn{2}{|c|}{$\begin{array}{l}\text { Keluarga \& } \\
\text { waktu luang }\end{array}$} & \multicolumn{2}{|c|}{$\begin{array}{c}\text { Hubungan } \\
\text { pertemanan }\end{array}$} & \multicolumn{2}{|c|}{$\begin{array}{c}\text { Lingkungan } \\
\text { sekolah\&belajar }\end{array}$} \\
\hline & $\mathrm{r}$ & $\mathrm{p}$ & $\mathrm{r}$ & $\mathrm{p}$ & $\mathrm{r}$ & $\mathrm{p}$ & $\mathrm{r}$ & $\mathrm{p}$ & $\mathrm{r}$ & $\mathrm{p}$ \\
\hline ORA* & .130 & .121 & -.103 & .215 & -.081 & .326 & .062 & .452 & -.146 & .076 \\
\hline REC* & .065 & .439 & .021 & .804 & .010 & .900 & .004 & .959 & -.123 & .138 \\
\hline PER* & .187 & $.025 * *$ & .043 & .606 & -.018 & .832 & -.046 & .576 & -.047 & .570 \\
\hline
\end{tabular}

Peneliti juga ingin melihat kaitan antara perilaku online beresiko dengan tingkat sosial ekonomi, frekuensi, dan durasi penggunaan dengan analisis korelasi Spearman dan perbedaannya pada laki-laki dan perempuan dengan analisis t-test. Variabel perilaku online beresiko tidak memiliki hubungan yang signifikan dengan tingkat sosial ekonomi, frekuensi, dan durasi penggunaan internet. Sementara itu, perilaku online beresiko memiliki perbedaan berdasarkan jenis kelamin. Perilaku online beresiko ditinjau secara aktivitas, secara penerima dan penyebar konten seksual lebih tinggi terjadi pada lakilaki daripada perempuan $(\mathrm{t}=2.82, \mathrm{p}=.005$, $\mathrm{t}=3.55, \mathrm{p}=.001$, dan $\mathrm{t}=3.40, \mathrm{p}=.001)$.

\section{DISKUSI}

Penelitian ini bertujuan untuk mengetahui hubungan antara parental mediation dan kualitas hidup remaja dengan perilaku online beresiko. Hasil penelitian menunjukkan bahwa parental technical mediation berkaitan dengan perilaku online beresiko penyebar konten seksual dan kualitas hidup domain kesehatan dan aktivitas fisik berhubungan secara positif dan signifikan namun hubungannya lemah. Sementara, tipe tipe parental mediation lainnya dan domain kualitas hidup lainnya tidak berkaitan dengan perilau online beresiko pada remaja di Jakarta.

Hasil penelitian yang menunjukkan bahwa parental technical mediation berkaitan dengan perilaku online beresiko pada remaja sebagai penyebar konten seksual sesuai dengan penelitian Li dkk (2000), Sasson dan Mesch (2014), dan Suwarni (2009) yang mengatakan bahwa persepsi anak terhadap buruknya (rendahnya) parental mediation berkaitan dengan keterlibatan remaja pada perilakuperilaku beresiko seperti perilaku seksual tidak aman, penggunaan atau pengedaran NAPZA, dan termasuk juga perilaku online berbahaya. Pada penelitian ini, remaja yang tidak mendapatkan parental technical mediation lebih cenderung terlibat dengan perilaku online beresiko penyebar konten seksual, meskipun keterlibatan yang dinyatakan partisipan tidak intensif. Menuru peneliti, hal ini paling tidak mengindikasikan bahwa orang tua tetap berperan dalam mengawasi penggunaan media internet oleh remaja mereka. Pengawasan orang tua ini akan lebih baik jika dimulai sejak dini ketika orang tua mengenalkan perangkat internet kepada anak-anak mereka.

Faktor lain yang dapat berkaitan dengan perilaku online beresiko adalah faktor psikososial remaja, terutama dari aspek psikologi dan sosialnya. Aspek psikologi dan lingkungan sosial ini masuk ke dalam ranah kualitas hidup remaja yang peneliti ukur. Hasil penelitian menunjukkan, dari empat domain kualitas hidup remaja, hanya kesehatan dan aktivitas fisik yang berkaitan positif signifikan dengan perilaku online beresiko sebagai penyebar konten seksual. Artinya, semakin remaja mempersepsi dirinya sehat dan aktif secara fisik, semakin mungkin remaja terlibat dalam perilaku online beresiko. Hasil tersebut berbeda dengan penelitianpenelitian sebelumnya yang menyatakan bahwa faktor yang berkaitan dan dapat menjadi kontributor perilaku beresiko remaja, termasuk juga perilaku online 
beresiko adalah masalah emosional, masalah pertemanan, dan hiperaktivitas (Goodman, dkk, dalam Livingstone \& Görzig 2014). Penelitian lain juga menunjukkan bahwa semakin baik kesejahteraan fisik remaja maka semakin rendah penggunaan media layar kaca (Finne dkk, 2014; Iannotti dkk, 2009). Jika menelaah dari hasil-hasil penelitian tersebut, hubungan yang positif namun lemah antara kesehatan fisik dengan perilaku menyebar konten seksual dapat berkaitan dengan persepsi keaktifan partisipan dan mungkin dapat berkaitan dengan hiperaktivitas seperti yang dimaksud Goodman dkk (dalam Livingstone \& Görzig, 2014). Remaja yang memiliki kecenderungan hiperaktivitas perlu mendapatkan stimulasi kegiatan yang lebih besar, sehingga ketika mereka tidak menemukan aktivitas yang menantang secara positif, maka mereka akan lebih cenderung terlibat pada aktivitas yang beresiko, termasuk perilaku online menyebarkan konten seksual.

Tidak adanya kaitan antara model parental mediation dan domain kualitas hidup dengan variabel perilaku online beresiko pada remaja dapat saja disebabkan berbagai faktor. Faktor yang pertama adalah terkait dengan aitem-aitem dalam kusioner perilaku online beresiko. Beberapa aitem pada alat ukur ini menggambarkan perilaku online beresiko yang berkaitan dengan konten seksual. Hal ini dapat memiliki efek social desirability yang tinggi bagi remaja meskipun peneliti menggunakan aitem dengan pernyataan konten seksual yang tidak spesifik. Hal ini dibuktikan dari persebaran 148 partisipan, hampir semua partisipan tidak ada yang mengisi aitemaitem variabel ini dengan intensitas yang tinggi. Selain itu, sebagain besar pengambilan data dilakukan secara massal di kelas. Meskipun peneliti telah memastikan kerahasiaan data dan identitas serta memberikan anjuran partisipan untuk bekerja sendiri namun tetap ada kecenderungan partisipan merasa khawatir menjawab apa adanya karena teman sebangku mereka dapat tiba-tiba melihat jawaban mereka. Penelitian selanjutnya dapat mengambil partisipan di tempattempat yang sering menjadi perkumpulan remaja melakukan aktivitas seperti game online dan sebagainya.

Berdasarkan jenis kelamin, peneliti menemukan perbedaan perilaku online beresiko pada laki-laki dan perempuan. Partisipan laki-laki lebih besar terpapar pada aktivitas online beresiko, penerima dan penyebar konten seksual dibandingkan perempuan. Hal ini sejalan dengan temuan Peter dan Volkenburg, serta Livingstoner dkk (dalam Paluckaitė \& -Matulaitienè, 2016) bahwa remaja laki-laki lebih cenderung terlibat dengan perilaku online beresiko dibandingkan remaja perempuan karena remaja perempuan lebih memberikan perhatian terhadap privasi mereka dibandingkan remaja laki-laki. Menurut peneliti, hal ini dapat terjadi karena laki-laki memiliki keingintahuan yang lebih tinggi berkaitan dengan aspek seksualitas dan lebih dimaklumi ketika mengeksplorasi konten yang berkaitan dengan seksualitas. Hal ini juga sejalan dengan penelitian Lestari dkk (2015) yang menemukan bahwa intensitas mengakses kontes pornografi lebih banyak dilakukan oleh remaja laki-laki sehingga mereka juga lebih terlibat dengan perilaku seksual pranikah. Sarwono (dalam Lestari dkk, 2015) mengatakan bahwa remaja laki-laki memang lebih terbuka terhadap seksualitas dan kebanyakan hubungan seksual pranikah yang terjadi pada remaja diawali dengan agresivitas remaja laki-laki.

Berdasarkan kebiasaan menggunakan internet, perilaku online beresiko tidak memiliki hubungan dengan frekuensi dan durasi penggunaan. Hasil penelitian ini tidak sejalan dengan temuan Wach dkk (dalam Paluckaitè \& Matulaitienè, 2016) dan Paluckaitè dan Matulaitienè (2016) yang menyatakan bahwa semakin lama remaja menggunakan internet, semakin cenderung mereka dapat terlibat perilaku online beresiko. Peneliti juga menemukan bahwa tingkat sosial ekonomi remaja pada 
penelitian ini tidak berkaitan dengan perilaku online beresiko. Hasil ini juga tidak sejalan dengan Livingstone dan Helsper (2007) serta Livingstone dan Haddon (2009) yang mengatakan bahwa keadaan sosial remaja yang buruk berkaitan dengan perilaku online beresiko pada remaja. Ketidaksesuaian ini menurut peneliti dapat berkaitan dengan distribusi partisipan yang tidak merata baik secara sosiodemografi atau pun kelompok yang benar-benar mewakili perilaku online beresiko yang terkait seksualitas.

\section{SIMPULAN}

Parental technical mediation berkaitan secara negatif dan signifikan dengan perilaku online beresiko penyebar konten seksual. Kualitas kesehatan dan aktivitas fisik juga memiliki hubungan yang signifikan dengan perilaku online beresiko penyebar konten seksual. Sedangkan, keseluruhan domain kualitas hidup remaja dan parental mediation tidak berkaitan secara signifikan dengan variabel perilaku online beresiko.

\section{SARAN}

1. Melibatkan pengambilan sampel pada lokasi bermain game online atau warnet karena tempat ini juga sering dijadikan tempat mengakses internet oleh berbagai kalangan.

2. Melibatkan pengambilan kuesioner melalui wawancara sehingga peneliti dapat menjalin raport terlebih dahulu, memastikan keamanan dan keadaan partisipan dalam menjawab kuesioner lebih personal.

3. Literasi penggunaan internet yang aman secara teknis dan interaksi perlu ditingkatkan kepada seluruh lapisan masyarakat. Khususnya orang tua atau penyedia sarana internet bagi remaja perlu memastikan setting keamanan pada perangkat yang digunakan remaja untuk mengakses internet.

\section{UCAPAN TERIMA KASIH}

Peneliti mengucapkan terima kasih kepada Yayasan Universitas YARSI yang telah memberikan dukungan pendanaan untuk penelitian ini. Peneliti juga mengucapkan kepada Komite Etik Penelitian Lembaga Penelitian Universitas YARSI yang telah memberikan persetujuan etik untuk pelaksanaan penelitian.

\section{DAFTAR PUSTAKA}

Barlett, N. D., Gentile, D. A., Barlett, C. P., Eisenmann, C., \& Walsh, D. A. (2011). Sleep as a mediator of screen time effects on US childre' s Health Outcomes: A prospective study. Journal of Children and Media, (November), 37-41. https://doi.org/10.1080/17482798.201 1.633404

Baumgartner, S. E., Valkenburg, P. M., \& Peter, J. (2010). Unwanted online sexual solicitation and risky sexual online behavior across the lifespan. Journal of Applied Developmental Psychology, 31(6), 439-447. https://doi.org/10.1016/J.APPDEV.20 10.07.005

Berman, A. H., Liu, B., Ullman, S., Jadbäck, I., \& Engström, K. (2016). Children's Quality of Life Based on the Ratings and Child-Parent Agreement in a Swedish Random Population Sample, 1-15. https://doi.org/10.1371/journal.pone.0 150545

Braun-Courville, D. K., \& Rojas, M. (2009). Exposure to sexually explicit web sites and adolescent sexual attitudes and behaviors. Journal of Adolescent Health, 45(2), 156-162. https://doi.org/10.1016/j.jadohealth.20 08.12.004

Dürager, A., \& Sonck, N. (2014). Testing the reliability of scales on parental internet mediation. Retrieved from http://eprints.lse.ac.uk/60220/1/EU_K ids_Online_ScalesReport2014.pdf.

Finne, E., Bucksch, J., Lampert, T., \& 
Kolip, P. (2014). Physical activity and screen-based media use : crosssectional associations with healthrelated quality of life and the role of body satisfaction in a representative sample of German adolescents, 1(1), 15-30.

Houck, C. D., Barker, D., Rizzo, C., Hancock, E., Norton, A., \& Brown, L. K. (2014). Sexting and Sexual Behavior in At-Risk Adolescents. Pediatrics, 133, e276-e282. https://doi.org/10.1542/peds.20131157.

Iannotti, R. J., Kogan, M. D., Janssen, I., \& Boyce, W. F. (2009). Patterns of Adolescent Physical Activity, ScreenBased Media Use and Positive and Negative Health Indicators in the U.S. and Canada. Journal of Adolescents' Health, 44(5), 493-499.

https://doi.org/10.1016/j.jadohealth.20 08.10.142.Patterns.

Lestari, A. Y., Suherni, \& Kusmiyati, Y. (2015). Hubungan intensitas mengakses situs porno dengan perilaku seksual pranikah remaja. Jurnal Kesehatan Ibu Dan Anak, 7(1), 5-9.

Li, X., Stanton, B., \& Feigelman, S. (2000). Impact of Perceived Parental Monitoring on Adolescent Risk Behavior Over 4 Years. Journal of Adolescent Health, 27(1), 49-56.

Livingstone, S., \& Görzig, A. (2014). When adolescents receive sexual messages on the internet : Explaining experiences of risk and harm. Computers in Human Behavior, 33, $8-15$. https://doi.org/10.1016/j.chb.2013.12. 021.

Livingstone, S., \& Haddon, L. (2009). EU kids online (Accepted version ). Journal of Psychology, (January 2009), 239-236.

https://doi.org/10.1027/00443409.217.4.236.

Livingstone, S., Haddon, L., Görzig, A., \& Olafsson, K. (2011). Full findings and policy implications from the EU Kids Online survey of 9-16 year olds and their parents in 25 countries. Risks and safety on the internet: The perspective of European children. Livingstone, S., \& Helsper, E. J. (2007). Taking risks when communicating on the internet : the role of offline socialpsychological factors in young people 's vulnerability to online risks Article. Information, Communication, and Society, 10(October), 619-. https://doi.org/10.1080/13691180701 657998.

Mesch, G. S. (2009). Parental Mediation, Online Activities, and Cyberbullying, 12(4). https://doi.org/10.1089/cpb.2009.0068 Naja, Z. S., Agushybana, F., \& Mawarni, A. (2017). Hubungan pengetahuan, sikap mengenai seksualitas dan paparan media sosiak dengan perilaku seksual pranikah pada remaja di beberapa SMA kota Semarang triwulan II Tahun 2017. Jurnal Kesehatan Masyarakat, 5(4), 282293.

Noll, J., Shenk, C. E., Barnes, J. E., \& Haralson, K. J. (2013). Association of Maltreatment With High-Risk Internet Behaviors and $\mathrm{Of} \mathrm{fl}$ ine Encounters. Pediatrics, 131(2), e510-e517. https://doi.org/10.1542/peds.20121281.

Paluckaite, U., \& -Matulaitienè, K. Ž. ardeckait è. (2016). Students ' Engagement in Risky Online Behaviour : The Comparison of Youth and Secondary Schools ': Students ' Engagement in Risky Online Behaviour: The Comparison of Youth and Secondary Schools '. In The European Proceeding of Social and Behavioral Science (pp. 266-273). https://doi.org/10.15405/epsbs.2016.0 7.02.26. 
Ramadani, S. D., \& Hanna, I. D. (2019).

Internet dan perilaku seksual remaja pesisir madura: Studi cross.

Dinamika Sosial Budaya, 21(2), 9197.

Sasson, H., \& Mesch, G. (2014). Parental mediation, peer norms and risky online behavior among adolescents. Computers in Human Behavior, 33, 32-38.

https://doi.org/10.1016/J.CHB.2013.1 2.025 .

Suwarni, L. (2009). Monitoring Parental dan Perilaku Teman Sebaya Terhadap Perilaku Seksual Remaja SMA Di Kota Pontianak. Jurnal Promosi Kesehatan Indonesia, 4(2), 127-133.

Ucar, T., Golbasi, Z., \& Erenel, A. S. (2016). Sexuality and the internet: A study of the perspectives of Turkish University students.

Cyberpsychology, Behavior, and Social Networking, 19(12), 22-25. https://doi.org/10.1089/cyber.2016.04 33.

Volkenburg, P. M., Peter, J., \& Scouten, A. (2006). Friend Networking Sites and Their Relationship to.

Cyberpsychology and Behavior, 9, 584-590. https://doi.org/10.1089/cpb.2006.9.58 4. 